\title{
An increase of public transport and accessibility to urban amenities, some limited results: the case of the Lyons conurbation
}

\author{
D. Caubel \\ Laboratoire d'Economie des Transports, ENTPE, Ministry of Transport, \\ France
}

\begin{abstract}
The observable modifications in cities and on the individuals' way of life have impacts on the mobility practices, on the citizens' social conditions and on the capacity to reach activities. These evolutions can create, reduce or amplify chance inequalities to access activities between the different social groups. It leads to considering in the French decision-making processes, some aspects of the social dimension of sustainability, reduced to chances equalities and to the social implications of accessibility. The accessibility to urban amenities is based on the right to transport as a necessary condition for chance inequalities for all. In this context, we analyze whether an urban transportation system could reduce the population's chance inequalities in terms of social access to a basket of goods. We propose, on the Lyons conurbation, for the year 1999, to quantify the accessibility, by car or by public transport, of the rich or poor districts' inhabitants. Then, we explore the effects of an increase of public transport supply, based on the Urban Travel Plan for the Lyons conurbation. Does now provide improved accessibility and to reduce the inequalities between the richest and the poorest districts?
\end{abstract}

Keywords: accessibility, basket of goods, chances (in)equalities, urban transport. 


\section{Introduction}

According to Bourdieu [2], ways of life constitute "the clearest sign of individual or collective interiorization of measures linked to the positioning in the social environment"; because of this, individuals enable, with varying degrees of ability, their practices and social situations to be taken into account. Observable changes in urban society and evolving ways of life influence the practices of individual mobility (diversification of needs and reasons for trips) and their ability to take advantage of the town's activities. Our claim is that the analysis of ways of life reveals inequalities between individuals due to the interiorisation of the social space in which they live [2] and because of their different functioning modes. In view of the continued observation of inequalities, the social aspect of sustainable development takes on an essential role in decision-making processes. Thus, transport policies increasingly try to take into account the chance inequalities likely to emerge or to increase among individuals who may be able or not to take advantage of the town's activities.

According to Vandersmissen [18], the search for social cohesion involves a reduction of the socio-economic disparities. Access for all to the town's activities is at the root of the right to travel as a condition for equality of chances for all.

In this context, we will analyze the impact of an urban transport system and of its development on the reduction of chance inequalities in terms of the access to a basket of goods, defined by everyday activities which individuals need.

\section{Social implications of accessibility, significant focus of French decision makers}

If social integration through work makes it possible to fight against poverty, Jenson [7] reminds us that it is important to allow a fairer distribution of social opportunities. Thus, to fight against the social exclusion of the poorest, he insists on the fundamental issue of easy access to the town's amenities. Furthermore, Grafmeyer [5], claims that, since town dwellers tend to register in territories, in some cases adding to the economic, social, cultural or schooling difficulties, "the linked processes of segregation and exclusion make it more than ever necessary to take into account the real urban dimension of social problems" in urban planning policies - especially in urban transport. Indeed, the question of equal chances between individuals in terms of the access to the town's goods appears to be increasingly central to public action decision makers. This may in part be attributed to the observed growth of social inequalities [1]. It may also result from the persistence or even the worsening of segregation processes [11]. Even if this issue has long been present in French legislation [9], the 1990s witnessed its development especially with the law on Solidarity and Urban Renewal [10]. The "Perroux" [12] report of the "Commissariat Général du Plan" on the location of economic activities and the strategies to be adopted by the State focus on arguments justifying public action in favor of equity and social justice by underlining that society's values stress equal chances in accessing goods and the 
improvement of the living conditions of the poorest individuals. "One way to justify the aid given to the poorer regions is to highlight criteria of social justice, as defined by John Rawls and Amartya Sen" [12]. The author also insists that public collective services and facilities be maintained in sensitive areas, so that access to these services does not become more difficult than in other less sensitive areas. However this type of action does not automatically lead to a fairer situation. Will it not be necessary to control the services set up in zones said to be "not under-privileged" whilst maintaining these services in the poorest areas to avoid increasing the accessibility gap? The maintenance or the reduction of accessibility gaps between the poorest areas and the others, between the different social groups in terms of the town's activities, needs to be taken into account in the fight for social justice [12].

\section{Social accessibility to a basket of goods}

We have, within this context, developed an analysis methodology of chance (in) equalities of access to town activities. This methodology relies on the definition of a basket of goods and the definition of an access indicator to this basket of goods.

\subsection{Definition of a basket of goods}

Urban space activities may be defined as entities or objects, material or not, which confer advantages to individuals able to have access to them. Individuals wishing to take advantage of these advantages do so because they are expressing a need [13]. The relationship between need satisfaction and the activity is materialized by the physical or financial access to this activity, whether on a daily basis or not. This access enables a certain social cohesion and maintains the personal and social balance of individuals or households. A possible method of identification of the needs is based on the analysis of daily mobility habits. The finality of the trip is the access to an activity reflecting the individual's motivation.

Thus we define a basket of goods as being the interpretation of the reasons for the most recurrent trips - a minima structure- for individuals, regardless of their social group or standard of living.

We have chosen the definition of a single basket of goods for all individuals. This definition has a normative aspect, which may omit any reference to the different needs of the categories of individuals or which may conceal the revealed preferences of the various social groups. This eventually could mean defining a basket of goods which would differ according to the various categories of individuals and analyzing the results of their achievements. However, to analyze chance equalities between individuals, Amartya Sen claims it is necessary to take into consideration individual capabilities [16], before the actual achievements. Furthermore, we can consider that "equal access to consumer goods has grown in terms of a great number of criteria" [4]. Individuals may express the same needs without accessing the same kinds of 
goods, "should we define the democratic process as greater access to a good" [4]. This partly justifies the normative approach [3].

The basket of goods thus defined is composed of the reasons for trips and the activities linked to the domestic and personal environment. ("The domestic sphere refers to the family cell" [8].) The basket of goods thus includes shops, health services, administrative or assistance services. These activities correspond not only to an answer to the needs, but also to "logic of duty" of the individuals. [8]. In addition, the basket of goods also includes activities linked to the sociability need, which involves maintaining the social bond between members of the household, the family or with others. Beyond any constraints or obligations, this need corresponds to an access to non-compulsory activities during one's free time (leisure) to which is attributed "the logic of selfrealization" [8].

\subsection{Access indicator to basket of goods}

In order to measure chance (in)equalities between individuals we have designed an accessibility indicator to the basket of goods [3]. The principle of this indicator is as follows.

For each place of residence, for a basket of goods and for a mode of transport (private car or public transport), we focus on the travel time which enables the territory to be covered (potentially accessible zones) for which we obtain the average number of activities - of the service studied- for 1000 inhabitants of the agglomeration. Thus, the measure of accessibility to a basket of goods from a zone of residence is the maximum access time to each type of service from this same zone.

This accessibility indicator takes into account not only the urban transport system (private car, public transport), but also the interactions between activities and individuals. It implicitly includes the effects of competition between individuals and activities (density of activities and individuals and number of available activities in terms of the resident population). Thus, on the basis of a basket of goods initially equal for all individuals, we estimate the potential territory describing all possible destination choices - how far to go in terms of travel time- to be able to access them.

\section{Chance inequalities to access the activities of the Lyons conurbation in 1999 ?}

We present the analysis of access conditions to the basket of goods for the Lyons conurbation [3], by distinguishing wealthy and poor neighborhoods subject to the town's policy.

\subsection{Few inexploitations for private car users}

On the whole, without any distinction of location in wealthy or very poor neighborhoods, access to the basket of goods is characterized by a remarkable 
use of the private car. Whenever possible, individuals use a car to access the activities very rapidly, whatever their place of residence, their standard of living and their socio-economic specificities.

Access time is estimated at around ten minutes. It varies very little depending on the different neighborhoods of the Lyons conurbation.

Table 1: $\quad$ Access time in private car.

\begin{tabular}{|l|c|c|}
\hline & Access time to basket of goods & Variance \\
\hline $\begin{array}{l}\text { Wealthy } \\
\text { neighborhoods }\end{array}$ & 10.5 minutes & 1.1 minutes \\
\hline $\begin{array}{l}\text { Poor } \\
\text { neighborhoods }\end{array}$ & 10.3 minutes & 1 minute \\
\hline
\end{tabular}

\subsection{Unequal access to trip modes and unequal access to activities}

However, beyond this recurrence, we reveal the existence of chance inequalities from one neighborhood to another in terms of access to the basket of goods in 1999. These inequalities are mainly the result of unequal access to the car. While the inhabitants of wealthy neighborhoods are virtually all motorized, the number of non-motorized inhabitants in poor quarters reaches $31 \%$. The latter are therefore dependent on and potential users of public transport networks. However public transport is three times less efficient than the car to access a basket of goods (3.1 to 3.4).

Table 2: $\quad$ Unequal access to the car and chance inequalities.

\begin{tabular}{|c|c|c|c|c|c|}
\hline & \multicolumn{3}{|c|}{$\begin{array}{l}\text { Average access time to basket of } \\
\text { goods (in minutes) }\end{array}$} & \multicolumn{2}{|c|}{$\begin{array}{l}\text { Ratio of motorized } \\
\text { individuals }\end{array}$} \\
\hline & En VP & En TC & $\begin{array}{l}\text { Ratio } \\
\text { TC/VP }\end{array}$ & $0 \mathrm{VP}$ & $\begin{array}{l}1 \mathrm{VP} \text { ou } \\
\text { plus }\end{array}$ \\
\hline $\begin{array}{l}\text { Poor } \\
\text { neighborhoods }\end{array}$ & 10.3 & 32.2 & 3.1 & $31 \%$ & $69 \%$ \\
\hline $\begin{array}{l}\text { Wealthy } \\
\text { neighborhoods }\end{array}$ & 10.5 & 35.6 & 3.4 & $5 \%$ & $95 \%$ \\
\hline
\end{tabular}

\subsection{Unequal access to activities for public transport users}

Furthermore access chance inequalities exist between public transport users. Access times to basket of activity goods may vary by a ratio of 1 to 4 - or more between different neighborhoods of the city. These inequalities result from the quality of the public transport which varies from one area to another. Certain neighborhoods are very well served by public transport (network density, high frequency, commercial speed). Here this trip mode may compete with the private car to access a basket of goods. However other neighborhoods are penalized by weaker public transport supply. 


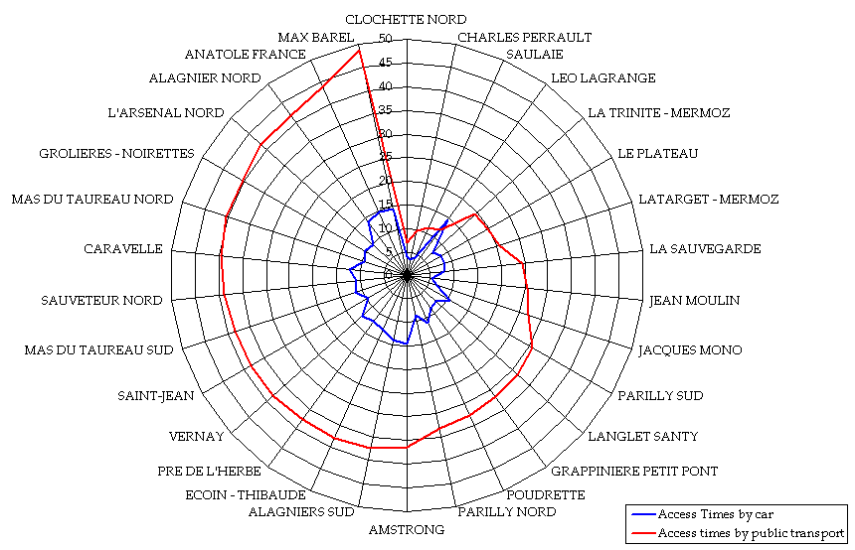

Figure 1: Unequal access to activities by public transport in the case of poorer neighborhoods.

\subsection{Developments in activity location, an explanation for chance inequalities}

The evolution in activity location within the Lyons conurbation between 1990 and 1999 is a factor which explains public transport access inequalities to city activities which were recorded in 1999. The urban dynamics of activities highlight a rise in inequalities between poor and wealthy neighborhoods.

If accessibility has undoubtedly improved both for private cars and public transport in wealthy peripheral neighborhoods, it has worsened in underprivileged neighborhoods. It all seems as if dominating social groups or wealthy classes, through their economic strength or consumer power, shape the division of land and the appearance of activities in the areas where they live to the detriment of more fragile populations or underprivileged classes $[6,15]$. This opposite evolution shows that, although wealthy neighborhoods and poor neighborhoods had identical access time to the basket of goods in 1990, the change in activity location has been exclusively favorable to the wealthiest. This has widened the gap in terms of access time with inhabitants of poor neighborhoods who may thus be qualified as losers.

This global trend is confirmed by the analysis of access conditions using public transport to each service of the basket of goods. For instance, the impact of changes in social service location highlights notable improvements in accessibility for inhabitants of wealthy neighborhoods, who benefit from the proximity of these services to their place of residence. However inhabitants of certain poor neighborhoods have seen their access to these services diminish, sometimes significantly (doubling of access time between 1990 and 1999). Nevertheless, this result is contrary to the goals of the 1992 public service charter, whose aim was to improve access to these services in sensitive neighborhoods. The assertive policies of the 1990s were not able to control the development of social services in areas around sensitive neighborhoods. This 
diagnosis confirms, to a lesser extent, Siblot's analysis [17], concerning policies aiming to adapt public services to underprivileged areas. These policies rely on studies describing the most underprivileged populations using a register of wretchedness (passivity, self doubt, humiliation). The policies therefore minimized or refuted "problems linked to the lack of services and are not in favor of additional services, but rather their adaptation through new specific services" [17]. This does not lead to "improvements in the proximity of public services" and the specification of social services "would seem to result in the exclusion of the inhabitants of sensitive areas" [17].

These results confirm the idea that the struggle against chance inequalities regarding access to activities of the city cannot be led without taking the location of activities that individuals need into consideration, but also with a global view of the urban morphology to better act on a local level. In addition to inequalities in accessing travel modes, the location of activities appears therefore as a determining factor in the appearance of access chance inequalities between individuals. However, urban development policies must not be designed solely in terms of activity location but in terms of transport policies.

\section{Development of public transport and reduction of inequalities?}

This is what we have tried to highlight by analyzing an improvement in public transport, based on the interpretation of the PDU of the Lyons conurbation and the implementation of dedicated bus routes.

\subsection{Improvement of accessibility for all ... but very limited}

The development of public transport contributes to a global improvement of accessibility to the basket of goods compared to the 1999 situation. This improved accessibility concerns almost all peripheral wealthy neighborhoods and the entire population of the poor neighborhoods. The latter neighborhoods would seem to benefit from the improved efficiency of the public transport supply of the Urban Travel Plan. This fits in with Rawls' "maximim" principle [14]. In fact, it is one of the objectives of the Urban Travel Plan which recommends servicing sensitive areas and linking them to the economic poles of the agglomeration.

Table 3: Accessibility gain for all.

\begin{tabular}{|l|c|c|c|}
\hline \multicolumn{1}{|c|}{ (in minutes) } & $\begin{array}{c}\text { Access time } \\
\text { using } \\
\text { Public transport } \\
\text { in } 1999\end{array}$ & $\begin{array}{c}\text { Access time gain } \\
\text { compared to } \\
1999\end{array}$ & $\begin{array}{c}\text { Wining } \\
\text { Population on at } \\
\text { least one service } \\
\text { of the basket of } \\
\text { goods }\end{array}$ \\
\hline Poor neighborhoods & 32.2 & $4.3(13.4 \%)$ & $100 \%$ \\
\hline Wealthy neighborhoods & 35.6 & $4.5(13.5 \%)$ & $97.8 \%$ \\
\hline
\end{tabular}


However, accessibility gains remain limited compared to the growth of the supply represented by the development of the public network system (average access gain of $13.5 \%$ for a growth of $40 \%$ of the supply) [3]. This limited impact confirms the need to combine transport policies with other urban planning policies concerning the location of activities, in order to guarantee the expected effect of a reduction of chance inequalities between neighborhoods.

\subsection{Improved access for wealthy neighborhoods}

In spite of this, accessibility improvement is greater for wealthy neighborhoods than for poorer ones. This may be explained by the speedy development of public transport in wealthy districts where access times in 1999 were slightly higher than in very poor neighborhoods. The Lyon Urban Travel Plan in fact underlines the will to set up strong axes able to serve these areas. The residents of these neighborhoods thus benefit from improved access to a rather significant basket of goods. This is especially interesting for individuals potentially dependent on public transport - and particularly the poorest inhabitants unable to use a private car.

\subsection{Limited responses to reduce inequalities}

If we assume that the wealthy and poor neighborhoods had the same access time to goods in 1990, the change in activity location leads to a loss of access for the poorest against a gain for the wealthier. We have noted a growth in chance inequalities between the two kinds of neighborhoods. If the development of public transport does lead to the improvement of access for all compared to 1999, it cannot however reduce inequalities between wealthy and poor neighborhoods in terms of all available services [3]. It only allows partial recovery of the loss of access of poor districts, due to the location of activities. The residents of the wealthy neighborhoods, however, benefit from both the urban dynamism of activities and the development of public transport.

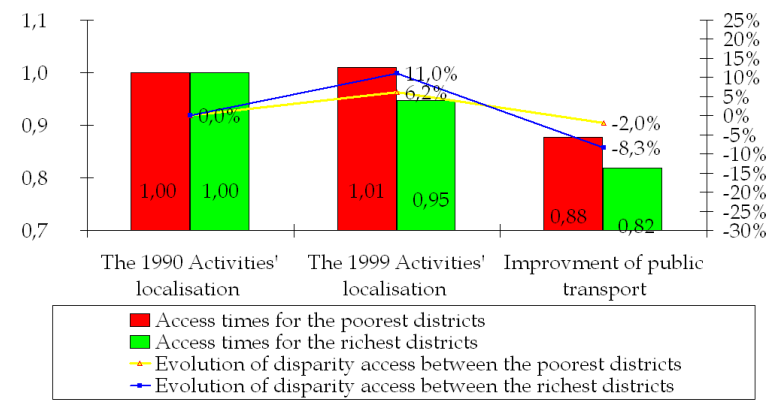

Figure 2: Difficult reduction of chance inequalities between wealthy and poor neighborhoods. 


\section{Conclusions}

A transport policy cannot universally claim to improve accessibility without taking into account the local and global contexts of urban morphology. Nor can it claim, alone, to heighten opportunities in all areas, without simultaneously adopting a policy focusing on the location of activities which individuals specifically need. Transport policies would enable this if, through political, legal, technical and financial means, they were part of a wider range of urban planning policies, to fight against the exclusion from the town's amenities of a sector of the population. Nevertheless, the development of urban public transport provides certain real answers, however imperfect and limited, to the conditions of access to the town's activities. This, to a certain extent does reveal the need to develop these transport networks which are indispensable, not only to the poorest.

Furthermore, in view of the power of the car to act as an equalizer of chances, wouldn't it be better for public authorities to equip the poorest households with a car? The subsidies required for the acquisition and use of a car for the poorest households of the Lyons conurbation would, in this event, be lower than the investment costs of the functioning of the Urban Travel Plan transport axes. This result is of course caricatural, since it does not take into account [3] conflicts with the environmental objectives. However shouldn't current policies, supported by environmental preoccupations be able to develop the necessary tools to assess and to identify potential social impacts which may be brought about whilst claiming to control mobility conditions and to reduce the use of the individual car in town? It would thus be necessary for these policies to be set in a more global framework, taking into account the location of activities, but also trying to conciliate issues of social justice with respect for the environment. This would entail knowledge and identification of socially disadvantaged groups of individuals. Without taking them into account, urban changes would probably maintain or even worsen chance inequalities in terms of town access and the social exclusion of certain sectors of the population.

\section{References}

[1] Avenel C. Sociologie des quartiers sensibles. Sociologie 128, Armand Colin, 2004

[2] Bourdieu P. La distinction: critique sociale du jugement. Ed Minuit, Paris, 1979

[3] Caubel D. Politique de transports et accès à la ville pour tous? Une méthode d'évaluation appliquée à l'agglomération lyonnaise. Thèse de Doctorat en Sciences Economiques, économie des transports, Université Lumière, Lyon, 2006.

[4] Dubet M. Les inégalités multipliées, L'aube, Poche Essai, 2000.

[5] Grafmeyer Y. L'école de Chicago. Naissance de l'écologie urbaine. Champs, Flammarion, 2004.

[6] Halbwachs M. Chicago, expérience ethnique, in Annales d'histoire économique et sociale, II, pp.11-42, 1932 
[7] Jenson J. Cohésion sociale et inclusion: quel est le programme de recherche? Horizons, vol 4, $\mathrm{n}^{\circ} 1$, pp.16-17, 2001.

[8] Kaufmann V. Mobilité quotidienne et dynamiques urbaines. La question $d u$ report modal, Lausanne, Presses Polytechniques et Universitaires Romandes, 2000.

[9] Loi d'Orientation sur les Transports Intérieurs, Paris, Journal Officiel de la République Française du 31 décembre 1982, 1982.

[10] Loi relative à la Solidarité et au Renouvellement Urbain, Paris, Journal officiel de la République Française du 13 décembre 2001.

[11] Mignot et Buisson (eds). Concentration économique et ségrégation spatiale. Economie Société Région, IWEPS, de Boeck Université, 2005.

[12] Mouhoud El M. Localisation des activités économiques et stratégies de l'Etat. Un scénario tendanciel et trois stratégies d'action régionale pour l'Etat, Rapport “ Perroux” du Commissariat Général du Plan, 2005.

[13] Reboul S. Le rasoir philosophique. L'existence de la condition humaine. Besoin et désir. http://sylvainreboul.free.fr/des.htm.

[14] Rawls J, Théorie de la Justice, Coll. La couleur des idées, Le Seuil, Paris, 1971

[15] Roncayolo M. La villes et ses territoires, folio, Essai, Gallimard, 1997

[16] Sen A. Ethique et économie. Paris, Presse Universitaire de France, 1987.

[17] Siblot Y. Adapter les services publics aux habitants des "quartiers difficiles". Diagnostics misérabilistes et réformes libérales. in Actes de la Recherche en Sciences Sociales, fondateur: Pierre Bourdieu "Politique des espaces urbains. Penser, classer, administrer la pauvreté”, n¹59, Paris, Le Seuil, pp.70-87, 2005

[18] Vandersmissen M.-H. Mobilité, accessibilité et cohésion sociale. Session : Cohésion sociale et restructuration socio-économique régionale. in Actes du XXXVIII ${ }^{\text {ème }}$ Colloque de l'ASRDLF Développement Régional et cohésion sociale », Trois Rivières, Canada, 21-23 août 2002, 17 pages, 2002 